\title{
STRENGHTS-BASED CARE: UMA FILOSOFIA PARA CUIDAR EM ENFERMAGEM PROMOTORA DO EMPOWERMENT, DA AUTOEFICÁCIA E DA ESPERANÇA
}

\author{
STRENGHTS-BASED CARE: A PHILOSOPHY \\ TO CARE IN NURSING PROMOTING EMPOWERMENT, \\ SELF-EFFICACY, AND HOPE
}

\section{STRENGHTS-BASED CARE: UNA FILOSOFIA PARA CUIDAR EN ENFERMERIA PROMOVIENDO EL EMPODERAMIENTO, LA AUTOEFICACIA Y LA ESPERANZA}

\author{
Paula Encarnação ${ }^{1}$
}

Como citar este artigo: Encarnação P. Strenghts-based care: uma filosofia para cuidar em enfermagem promotora do empowerment, da autoeficácia e da esperança. Rev baiana enferm. 2021;35:e45203.

Atualmente, embora as/os enfermeiras/os tentem redirecionar os seus modelos de cuidados para um cuidar centrado na pessoa/família/comunidade, ainda prevalece dominante um modelo orientado para a resolução dos problemas que a pessoa tem, isto é, para o défice. Apesar de este modelo também "olhar" para a pessoa, não a consegue ver como uma totalidade, de forma integrada. Centra a sua atenção na compreensão da possível causa e dos sintomas relacionados com a patologia de base, com o órgão ou processo do sistema corporal disfuncional, tendo como meta curar, corrigir e/ou minimizar essa causa.

Partindo desse modelo fundamentado nos pressupostos biomédicos, a pessoa é frequentemente esquecida na sua singularidade, sendo mais simples para as/os enfermeiras/os rotularem-na de acordo com o que se encontra disfuncional. Em vez de se referirem, por exemplo, à "Sra. Vera", "Sra. Ana", "Sra. Maria" (nomes fictícios), referem-se, com alguma frequência: "A do pacemaker", "A da gastrite crónica", "A da úlcera gástrica". Este rótulo atribuído à pessoa desvia o foco da observação (integrada), considerada pedra angular da prática clínica, no contexto de cuidados de saúde em que se encontra. Se a/o enfermeira/o, durante a avaliação inicial, ignorar a singularidade da pessoa, pode tendencialmente focar-se apenas nos défices e problemas, deixando passar despercebidas as Forças da pessoa e o seu potencial de saúde e cura ${ }^{(1)}$.

A observação, enquanto precursora do juízo, raciocínio, tomada de decisão clínica e ação de enfermagem, exige excelentes competências de comunicação das/dos enfermeiras/os, com o propósito de recolher informação de um modo sistemático e intencional. Para isso, devem saber o que e o como observar $^{(1)}$.

Investigadora na Unidade de Investigação em Ciências da Saúde: Enfermagem (UICISA: E), Escola Superior de Enfermagem de Coimbra, Portugal. PhD, Professora Adjunta na Escola Superior de Enfermagem da Universidade do Minho. Portugal. pse@ese.uminho.pt. https://orcid.org/0000-0002-7458-8I 05. 
Alicerçados nos valores do Strenghts-Based Care $(\mathrm{SBC})^{(1)}$ (valor 1: saúde e cura; valor 2: singularidade da pessoa; valor 3: holismo e embodiment; valor 4: realidade objetiva/subjetiva e construção de significado; valor 5: autodeterminação; valor 6: pessoa e ambiente estão integrados; valor 7: aprendizagem, preparação e timing; valor 8: parceria colaborativa), eis-nos chegados ao momento de refletir sobre a prática clínica. O que e o como observar no Outro a quem cuidam num determinado momento da sua vida, o qual sofreu mudanças, adversidades, incapacidades, choques e traumas, passa a ter uma nova direção, uma nova meta. As/Os enfermeiras/os são desafiados a trabalhar com as pessoas e as famílias, numa verdadeira parceria colaborativa, e a tomarem, em conjunto, as melhores decisões sobre os cuidados de saúde que respondem às necessidades, objetivos e interesses dessas mesmas pessoas e famílias.

Ter o SBC como filosofia que guia a prática clínica da Enfermagem requer um cuidar centrado na pessoa/família/comunidade. Ajuda a desenvolver estratégias com a pessoa, de forma a que esta sinta-se capaz de atingir as suas próprias metas (empowerment) e a encontrar um novo significado na sua vida (esperança). Significa que o SBC torna-se um pré-requisito para a mudança, para a promoção da saúde, incentivando a pessoa a assumir a responsabilidade pela sua própria saúde ${ }^{(1)}$.

Ter um referencial teórico que guie e oriente a prática clínica permite às/aos enfermeiras/os responder questões de âmbito conceptual: Quais os problemas que requerem os meus conhecimentos e competências? Como é que me oriento enquanto profissional? Que competências e habilidades necessito ter para cuidar desta pessoa e da sua família? Como é que sei o que sei? O que conta para mim como evidência? ${ }^{(1)}$

Ter o SBC como referencial teórico permite deslocar o foco da atenção ${ }^{(1)}$ :

a) "de" se concentrarem nos défices, "para" trabalharem com as forças da pessoa;

b) "de" fazerem pela pessoa "para" trabalharem com a pessoa;

c) "de" se concentrarem na doença e no tratamento "para" se concentrarem no viver e no lidar com os desafios e os eventos adversos;

d) "de" assumirem a/o enfermeira/o como professor/a "para" assumirem a/o enfermeira/o e a pessoa como aprendizes;

e) "de" medirem um conjunto de resultados específicos "para" permitirem que a pessoa determine as suas próprias metas e medidas de sucesso.

Empoderar a pessoa significa ajudá-la a perceber que, embora não tenha escolhido ficar doente, ela possui o poder de escolher como irá lidar com aquilo que está a se passar com ela. Tal, significa que profissionais e a pessoa encontram-se numa relação de equidade no processo de tomada de decisão. Esta filosofia reconhece e respeita as experiências e os conhecimentos de ambos os parceiros. Isto não significa que a/o enfermeira/o transfira a responsabilidade para a pessoa. Isto significa que a/o enfermeira/o ouve a pessoa, reconhece a experiência da pessoa e, juntos, elaboram um plano de cuidados que é feito na medida de objetivos, necessidades, preferências, estilo de vida e circunstâncias da pessoa e da família. As pessoas, quando encorajadas a expressar-se, sentem-se fortalecidas e acreditam que têm a capacidade de encontrar soluções para os seus próprios problemas (autoeficácia) ${ }^{(1)}$.

Trabalhar com as forças implica treinar competências, técnicas, habilidades e perícia das/dos enfermeiras/os. Ser capaz de trabalhar com as forças requer o conhecimento das características de como uma qualidade converte-se numa força. Para a sua concretização, a/o enfermeira/o pode utilizar diferentes técnicas: fazer uma lista ou inventário das forças já existentes; perguntar aos doentes sobre as suas forças e seus recursos; partilhar as observações de forças com a pessoa; ensinar a pessoa a descobrir as suas próprias forças; evitar rótulos de diagnóstico para descrever a pessoa; dar elogio e louvores; focar-se em encontrar soluções, em vez de manter-se centrado nos problemas, e encontrar oportunidades para transmitir esperança. Pessoas com esperança têm melhor ajustamento psicológico e qualidade de vida. Quando as pessoas têm esperança, descobrem e recorrem a outras forças internas, como a coragem, 
a perseverança, e o humor ${ }^{(1)}$. "As/Os enfermeiras/os têm o poder de transformar o atual sistema de saúde [...] Eles têm o poder de trazer o toque humano para o ambiente dos cuidados de saúde que se encontra altamente sofisticado e tecnológico, ao tocar a vida de muitas pessoas. Têm o poder de criar uma nova cultura, uma ética de cuidar enraizada em valores de compaixão e conhecimento que respeitam o espírito humano e dão dignidade à pessoa. Eles têm o poder para restaurar a centralidade da relação enfermeira/o-doente e a pessoa como o foco do cuidar. O SBC concede este poder às/aos enfermeiras/os." ${ }^{(1: x x x v i i i) .}$

\section{Contribuições:}

A autora é responsável pela concepção do projeto, análise e interpretação dos dados, redação do artigo, revisão e aprovação final da versão a ser publicada, e por todos os aspectos do trabalho, na garantia da exatidão e integridade de qualquer parte da obra.

\section{Referências}

1. Gottlieb LN. O cuidar em enfermagem baseado nas forças: saúde e cura para a pessoa e família. Loures (PT): Lusodidacta; 2016.

Recebido: 25 de junho de 2021

Aprovado: 13 de julho de 2021

Publicado: 5 de agosto de 2021

A Revista Baiana de Enfermagem utiliza a Licença Creative Commons - Atribuição-NãoComercial 4.0 Internacional. https://creativecommons.org/licenses/by-nc/4.0/

Este artigo é de acesso aberto distribuído sob os termos da Licença Creative Commons (CC BY-NC). Esta licença permite que outros remixem, adaptem e criem a partir do seu trabalho para fins não comerciais. Embora os novos trabalhos tenham de lhe atribuir o devido crédito e não possam ser usados para fins comerciais, os usuários não têm de licenciar esses trabalhos derivados sob os mesmos termos. 